УДК 619:616.993.192.66:636.7

(C) 2013

Грубіч П. Ю., кандидат ветеринарних наук,

Курман А. Ф., кандидат біологічних наук,

Лепета Л. В., науковий співробітник,

Пархоменко $С$. А., молодший науковий співробітник

Інститут свинарства і АПВ НААН України

\title{
РОЗРОБКА ПЛР ТЕСТ-СИСТЕМИ ДЛЯ ВИДОВОЇ ІДЕНТИФІКАЦЇ̈ ЗБУДНИКІВ БАБЕЗІОЗУ ТВАРИН
}

\section{Рецензент - кандидат ветеринарних наук I. М. Ксьонз}

Розроблена система олігонуклеотидних праймерів, що дозволяє ампліфікувати в ПЛР ділянки гену $18 S$ pРНК 6 видів роду Babesia. Наведено особливості конструювання праймерів та випробування мультиплексної ПЛР тест-системи для ідентифікаиії представників роду Babesia. Визначені довжини ампліфікованих фрагментів - від 299 до 258 пар нуклеотидів для Babesia canis, Babesia divergens, Babesia caballi, Babesia major, Babesia bovis. Дослiджено 342 зразки крові від різних видів тварин $i$ встановлено $100 \%$ збіг із результатами мікроскопічних досліджень.

Ключові слова: бабезіоз, діагностика, тестсистема, ідентифікачія, праймери, нуклеотиди.

Постановка проблеми. Бабезіоз в Україні $\epsilon$ поширеною серед домашніх тварин сезонною хворобою і займає за кількістю випадків і тяжкістю перебігу одне з провідних місць серед інвазійних захворювань.

Відомо, що у кожного виду тварин бабезіоз викликає певний вид збудника, проте тривалий час видова ідентифікація здійснювалася виключно за морфологічними ознаками збудника, які варіювали в досить широких межах. Однак, остаточно не 3'ясовано: чи може викликати захворювання в одного виду тварин збудник іншого виду.

Наразі $є$ недостатньо вивченими належність до роду Babesia окремих видів збудника, видові властивості збудників та патогенез захворювання, зокрема, механізми, що пригнічують розвиток збудника в організмі.

Відсутні ефективні засоби специфічної профілактики бабезіозу, а хіміотерапія $є$ надзвичайно токсичною, з вираженою побічною дією.

Аналіз останніх досліджень і публікацій, у яких започатковано розв'язання проблеми. Використання молекулярно-генетичних методів дало змогу внести певну ясність у класифікацію родини Piroplasmida ссавців та розділити їх на 4 первинні групи, зокрема: родів Babesia, Theileria, Cytauxzoon та Babesia microti [1]. У світовій практиці використовуються засоби ідентифікації бабезій, що розроблені на основі молекулярно-генетичних методів. Однак вони дають змогу визначати лише окремі види бабезій [2-4]. В Україні таких засобів розроблено не було.

Метою нашої роботи була розробка системи ідентифікації бабезій на основі молекулярногенетичних особливостей та конструювання діагностичної ПЛР тест-системи.

Основним завданням є розробка системи олігонуклеотидних праймерів для виготовлення ПЛР тест-системи 3 видового типування бабезій та молекулярної діагностики бабезіозу тварин.

Методика досліджень. За допомогою програми MEGA [5] визначали консервативні та варіабельні, в межах роду Babesia, ділянки гену $18 \mathrm{~S}$ рРНК. Консервативні послідовності були використані для розробки ПЛР-тест системи, що дозволяла ампліфікувати послідовності ділянок гену $18 \mathrm{~S}$ рPHК 6 видів роду Babesia: Babesia canis, Babesia divergens, Babesia caballi, Babesia major, Babesia bovis. Варіабельні ділянки гену $18 \mathrm{~S}$ рРНК були використані для розробки видоспецифічної системи олігонуклеотидних праймерів, яка давала змогу ідентифікувати три види роду Babesia, а саме: Babesia canis, Babesia divergens та Babesia bovis.

Стуктуру олігонуклеотидних праймерів визначали 3 використанням програми FastPCR [6]. Параметри для розробки праймерів були наступні: довжина від 18 до 24 нуклеотидів, температура відпалу від $58^{\circ} \mathrm{C}$ до $63{ }^{\circ} \mathrm{C}$. У результаті була розроблена система олігонуклеотидних праймерів (Babesia sp.): прямий BSPF та зворотній $B S P R$, що теоретично дозволяли б ампліфікувати в ПЛР ділянки гену $18 \mathrm{~S}$ рРНК 6 видів роду Babesia: Babesia canis, Babesia divergens, Babesia caballi, Babesia major, Babesia bovis. Нуклеотидні послідовності праймерів наведено в таблиці 1. 
ВЕТЕРИНАРНА МЕДИЦИНА

1. Назва, нуклеотидна послідовність та характеристики праймерів для діагностичної мультиплексної ПЛР-тест системи представників роду Вабеsіа

\begin{tabular}{|c|c|c|c|c|c|}
\hline $\begin{array}{c}\text { № } \\
3 / \Pi\end{array}$ & Праймер & Послідовність $\left(5^{*}-3^{*}\right)$ & $\begin{array}{c}\text { Довжина } \\
\text { (п. н.) }\end{array}$ & $\begin{array}{c}\text { Температура } \\
\text { відпалу }\left({ }^{\circ} \mathrm{C}\right)\end{array}$ & CG (\%) \\
\hline 1 & BCANF & gtgacccaaaccctcaccaga & 21 & 59.0 & 57,1 \\
\hline 2 & BSPF & ccattggaggggaagtctggt & 21 & 59,4 & 57,1 \\
\hline 3 & BDIVR & tcccaaaacceaactecaatctcc & 24 & 59,9 & 50 \\
\hline 4 & BBOVR & ccaaagtcaaccaacggtacgaca & 24 & 593 & 50 \\
\hline 5 & BSPR & acgaatgcccccaaccgtt & 19 & 59,6 & 57,9 \\
\hline
\end{tabular}

Для видової ідентифікації нами запропоновано мультиплексну систему з двох прямих BSPF, BCANF i трьох зворотних BSPR, BBOVR, BDIVR пар праймерів. Останні, а також довжини продуктів ПЛР, що дозволяють видоідентифікувати три види роду Babesia, наведено в табл. 3. У цій системі використовуються також олігонуклеотидні праймери для загального визначення представників роду Babesia, а специфічність визначалась іншим праймером із пари.

Виділення нуклеїнових кислот із біологічного матеріалу проводили із застосуванням реагенту «Chelex-100», згідно СОУ 85.2-37-206:2004. Біоматеріалом були зразки венозної крові від різних видів тварин. Ампліфікацію проводили на програмованому термостаті ТЕРЦИК-2 (ДНКТехнологии, Россия) 3 використанням набору peareнтів «Тапотили» (ГосНИИ генетики микроорганизмов, Россия). Продукти ампліфікації аналізували у $8 \%$ поліакриламідному та $2 \%$ агарозному гелях. Як маркер молекулярної маси використовували ДНК плазміди pBR322, гідролізованої ендонуклеазою MspI та pUC19, гідролізованої ендонуклеазою MspI. Візуалізацію продуктів ампліфікації здійснювали шляхом фарбування гелів бромистим етидієм і фотографуванням на транс-ілюмінаторі в ультрафіолетовому світлі.

Результати досліджень. Для різних представників роду Babesia були визначені різні довжини ампліфікованих фрагментів ДНК - від 299 до 268 пар нуклеотидів, обумовлених дещо різним внутрішнім змістом консервативної ділянки гену $18 \mathrm{~S}$ pPHK.

\section{2. Довжини продуктів ПЛР представників роду Вавеsіа, що дозволяють ампліфікувати за допомогою пари праймерів BSPF/BSPR (Babesia sp.)}

\begin{tabular}{|c|c|c|c|}
\hline & Вид & Номер міжнародної бази даних & Довжина ПЛР продукту (п.н.) \\
\hline \multirow{3}{*}{1} & Babesia canis & EU711061 & $298 \mathrm{bp}$ \\
\hline & Babesia canis & FJ200218 & 298 bp \\
\hline & Babesia canis & EU622793 & $298 \mathrm{bp}$ \\
\hline \multirow{3}{*}{2} & Babesia divergens & EU182595 & $298 \mathrm{bp}$ \\
\hline & Babesia divergens & DQ866843 & $298 \mathrm{bp}$ \\
\hline & Babesia divergens & DQ866844 & $298 \mathrm{bp}$ \\
\hline \multirow{2}{*}{3} & Babesia caballi & EU888901 & $287 \mathrm{bp}$ \\
\hline & Babesia caballi & EU642514 & $287 \mathrm{bp}$ \\
\hline \multirow{2}{*}{4} & Babesia major & EU622907 & $287 \mathrm{bp}$ \\
\hline & Babesia sp.CS & EU622824 & $285 \mathrm{bp}$ \\
\hline 5 & Babesia bigemina & DQ785311 & $284 \mathrm{bp}$ \\
\hline \multirow{10}{*}{6} & Babesia bovis & FJ426364 & $268 \mathrm{bp}$ \\
\hline & Babesia bovis & EF458215 & $270 \mathrm{bp}$ \\
\hline & Babesia bovis & EF458214 & $267 \mathrm{bp}$ \\
\hline & Babesia bovis & EF643475 & $268 \mathrm{bp}$ \\
\hline & Babesia bovis & EF643473 & $268 \mathrm{bp}$ \\
\hline & Babesia bovis & EF643466 & $268 \mathrm{bp}$ \\
\hline & Babesia bovis & AY150059 & $267 \mathrm{bp}$ \\
\hline & Babesia bovis & L19078 & $267 \mathrm{bp}$ \\
\hline & Babesia bovis & EU407240 & $267 \mathrm{bp}$ \\
\hline & Theileria equi & EU888906 & Не ампліфікується \\
\hline
\end{tabular}


ВЕТЕРИНАРНА МЕДИЦИНА

3. Пари праймерів та довжини продуктів ПЛР, щчо дозволяють видоідентифікувати три види роду Ваbesia

\begin{tabular}{|c|c|c|c|c|}
\hline № 3/п & Пара праймерів & Вид & $\begin{array}{c}\text { Довжина продукту } \\
\text { ампліфікації (п. н.) }\end{array}$ & Примітки \\
\hline 1 & BCANF/BSPR & Babesia canis & 325 & Видо-специфічні \\
\hline 2 & BSPF/BBOVR & Babesia divergens & 146 & Видо-специфічні \\
\hline 3 & BSPF/BDIVR & Babesia bovis & 233 & Видо-специфічні \\
\hline
\end{tabular}

4. Кількість досліджених методом ПЛР зразків за видами тварин

\begin{tabular}{|c|c|c|c|}
\hline Вид тварини & $\begin{array}{c}\text { Кількість досліджених } \\
\text { зразків }\end{array}$ & $\begin{array}{c}\text { Кількість позитивних } \\
\text { зразків }\end{array}$ & $\begin{array}{c}\text { Співпадання з резуль- } \\
\text { татами мікроскопії, \% }\end{array}$ \\
\hline Собака & 168 & 112 & 100 \\
\hline Кінь & 92 & 58 & 100 \\
\hline Велика рогата худоба & 67 & 41 & 100 \\
\hline Дрібна рогата худоба & 8 & 1 & 100 \\
\hline Людина & 7 & 0 & \\
\hline Усього & 342 & 212 & \\
\hline
\end{tabular}

$\begin{array}{lll}M & 1 & 2\end{array}$

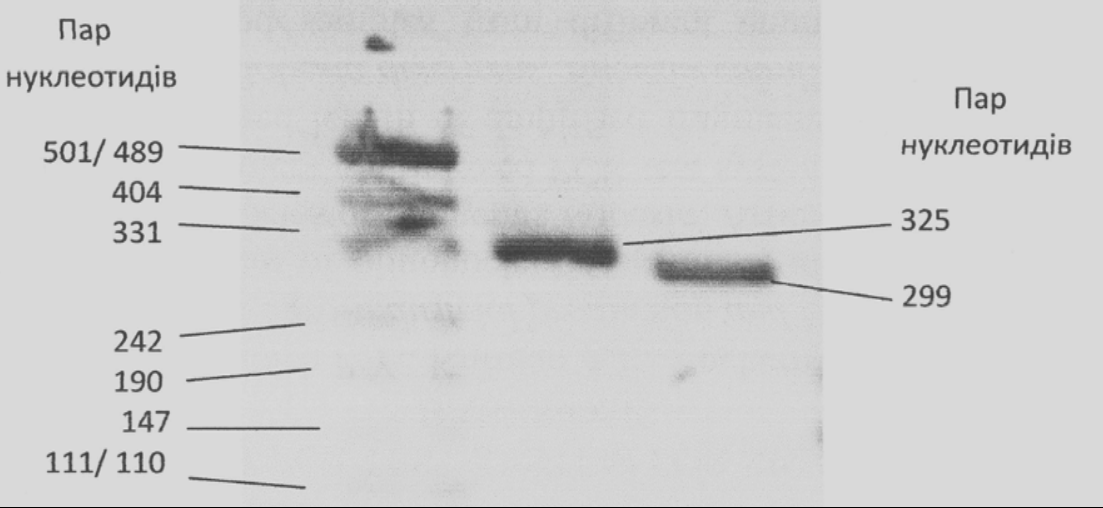

Рис. Електрофоретичне розділення у 2 \% агарозному гелі продуктів ампліфікації:

M - маркер молекулярної маси рUC19/MspI, 1 - продукт ПЛР специфічної ділянки гену $18 S$ рРНК

Babesia canis, 2 - продукт ПЛР консервативної ділянки гену $18 S$ рPHК представників роду Babesia.

Із метою діагностики максимально значної кількості представників видів роду Babesia була використана пара праймерів BSPF/BSPR. Нуклеотидна послідовність згаданих олігонуклеотидних праймерів наведена у таблиці 1. Ця система праймерів дозволяє ампліфікувати в ПЛР ділянки певного розміру гену $18 \mathrm{~S}$ рРНК представників шести видів роду Babesia (Babesia sp.) (табл. 2).

Пари праймерів та довжини продуктів ПЛР, що дозволяють видо-ідентифікувати види Babesia canis, Babesia divergens та Babesia bovis, наведені у таблиці 3.

Перевірка роботи на клінічному біоматеріалі діагностичних ПЛР-тест систем показала високу специфічність ампліфікації консервативної ділянки гену $18 \mathrm{~S}$ рРНК представників роду Babesia та специфічної ділянки гену $18 \mathrm{~S}$ рРНК виду
Babesia canis. Розділ продуктів ампліфікації показано на рисунку.

Випробування мультиплексної ПЛР тестсистеми проводили у лабораторних умовах у процесі дослідження зразків крові тварин, у тому числі діагноз на бабезіоз, яким був встановлений із використанням методу мікроскопії. Загалом досліджено 342 зразки крові. Дані щодо видової належності біологічних зразків наведена у таблиці 4.

Як видно із даних таблиці 4, генетичний матеріал бабезій був виявлений у $100 \%$ зразків крові, де бабезіоз діагностовано шляхом мікроскопії.

Висновки: 1. Таким чином, нами розроблена, сконструйована та випробувана мультиплексна ПЛР тест-система для видової ідентифікації трьох видів роду Babesia. 
2. Розміри ампліфікованих фрагментів ділянки гену $18 \mathrm{~S}$ рРНК, одержані у ході експериментальної перевірки ПЛР тест-системи, співпали 3 розмірами, що теоретично прогнозувалися.

3. Використання олігонуклеотидних праймеpiв BSPF, BSPR для ампліфікації консервативної ділянки гену $18 \mathrm{~S}$ рРНК теоретично дозволяють проводити загальну ідентифікацію представників роду Babesia. Крім того, за розмірами фраг-

\section{БІБЛІОГРАФІЯ}

1. Babesia microti-group parasites compared phylogenettcally by complete sequencing of the CCTeta gene in 36 isolates / [R. Nakajima, M. Tsuji, K. Oda, A. Zamoto-Niikura et all] // J. Vet. Med. Sci. - 2009. - V.71(1). - P. 55-68.

2. Specific and Highly Sensitive Primers for PCR Detection of Babesia bovis / [Nutcha Patarapadungkit, Suporn Nuchadomrong, Nison Sattayasai, Patchima Indrakamhang et all] // ScienceAsia. - 2004. - V 30. - P. 67-73.

3. The use of different diagnostic tools for Babesia and Theileria parasites in cattle in Menofia, Egypt / [Mohamed Nayel, Khaled Mohamed El-Dakhly, Mahmoud Aboulaila, Ahmed Elsify et all] // Parasitology Research. - 2012. - V. 111. - P. 10191024. ментів ПЛР здійснюється попередня ідентифікація 299 п. н. (Babesia canis, Babesia divergens), 285 п. н. (Babesia caballi, Babesia major), 268 п. н. (Babesia bovis).

4. Мультиплексну ПЛР тест-систему для видової ідентифікації представників роду Babesia доцільно надалі використовувати як у наукових дослідженнях, так і для проведення діагностики бабезіозу тварин.

4. PCR-based detection of Babesia bovis and Babesia bigemina in their natural host Boophilus microplus and cattle / [T. Oliveira-Sequeira, M. Oliveira, Jr. J. Araujo, A. Amarante] // Int. J. Parasitol. - 2005. - V. 35. - P. 105-111.

5. Kumar S. MEGA3: Integrated software for Molecular Evolutionary Genetics Analysis andsequence alignment / S. Kumar, K. Tamura, M. Nei // Briefings In Bioinformatics. - 2004. Vol. 5, №2. - P. 150-163.

6. «FastPCR» [Електронний ресурс] - Системні вимоги: Microsoft Windows 7/Vista/2003/XP/2000 (32-Bit (x86) or 64-Bit), 2 GB RAM, 1280x800 minimum screen resolution. - Режим доступу: http://primerdigital.com/fastpcr.html 